\title{
Quality of aged ewe meat in vacuum-packaging system for different storage periods
}

\section{Qualidade da carne maturada de ovelhas em sistema de embalagem a vácuo durante diferentes períodos de acondicionamento}

\author{
Camila Constantino ${ }^{1,2 *}$; Edson Luis de Azambuja Ribeiro ${ }^{3}$; Ana Maria Bridi; \\ Marina Avena Tarsitano²; Natália Albieri Koritiaki²; Louise Manha Peres; \\ Ivone Yurika Mizubuti ${ }^{3}$; Elzânia Sales Pereira ${ }^{6}$; Patrícia Guimarães Pimentel ${ }^{7}$
}

\begin{abstract}
Consumers believe tenderness to be most important organoleptic characteristic of meat. However, there is great variability in the tenderness of meat available to consumers; one method to reduce the variability and improve tenderness would be to promote meat aging. The aim of this study was to evaluate the quality of aged ewe meat. The experiment was conducted at the State University of Londrina. It was used eighteen Santa Ines ewes. After slaughter, the Longissimus dorsi muscle were collected and subjected to treatment, three different aging times: zero, four and eight days at $5 \pm 2{ }^{\circ} \mathrm{C}$. The increase in aging time caused a decrease in $\mathrm{pH}$. The $\mathrm{L}^{*}, \mathrm{a}^{*}$ and $\mathrm{c}^{*}$ values increase linearly with the aging period. The $b^{*}$ and $h^{*}$ values showed a quadratic regression. The mesophilic and psychrotrophic count showed a linear increase. The myofibrillar fragmentation index showed a quadratic regression, and the shear force decreased linearly. In a sensory analysis, a difference in the odor intensity of the meat was observed. The microbiological count indicated that the meat was fit for consumption. The aging promoted improvements in the quality of sheep meat.
\end{abstract}

Key words: Anaerobic, chroma, ovine, sensorial, tenderness

\section{Resumo}

Os consumidores acreditam que a maciez é a característica organoléptica mais importante da carne. No entanto, há grande variabilidade na maciez da carne disponível para os consumidores, um método de reduzir a variabilidade e melhorar a maciez seria promover a maturação da carne. O objetivo deste estudo foi avaliar a qualidade da carne maturada de ovelhas. O experimento foi conduzido na Universidade Estadual de Londrina. Foram utilizadas 18 ovelhas da raça Santa Inês. Após o abate, o músculo Longissimus dorsi foram coletados e submetidos ao tratamento, três diferentes tempos de maturação: zero, quatro e oito dias a $5 \pm 2{ }^{\circ} \mathrm{C}$. O aumento do tempo de maturação provocou uma redução no $\mathrm{pH}$.

\footnotetext{
${ }^{1}$ Parte da dissertação de Mestrado em Ciência Animal, da primeira autora, Universidade Estadual de Londrina, UEL, Londrina, PR.

${ }^{2}$ Discente(s) de Doutorado do Programa de Pós-Graduação em Ciência Animal, Universidade Estadual de Londrina, UEL, Londrina, PR. E-mail: caconstantino@hotmail.com; nataliaalbieri@hotmail.com; marina_avena@yahoo.com.br

${ }^{3}$ Profs. Drs. do Dept ${ }^{\circ}$ de Zootecnia, UEL, Londrina, PR. ${ }^{3,1}$ Bolsista de Produtividade do CNPq. Londrina-Pr. E-mail: elar@uel.br; mizubuti@uel.br

${ }^{4}$ Prof $^{\mathrm{a}}$ Dr $^{\mathrm{a}}$. do Dept ${ }^{\mathrm{o}}$ de Zootecnia, UEL, Londrina, PR. E-mail: ambridi@uel.br

${ }^{5}$ Discente de Mestrado do Programa de Pós-Graduação em Ciência Animal, Universidade Estadual de Londrina, UEL, Londrina, PR. E-mail: louise_mp@zootecnista.com.br

${ }^{6}$ Prof $^{a}$ Dr $^{\mathrm{a}}$. do Dept ${ }^{-}$de Zootecnia, Universidade Federal do Ceará, UFC, Ceará, CE. Bolsista de Produtividade do CNPq. E-mail: elzania@hotmail.com

${ }^{7}$ Prof $^{\mathrm{a}} \mathrm{Dr}^{\mathrm{a}}$ do Dept ${ }^{\mathrm{o}}$ de Zootecnia, UFC, Ceará, CE. E-mail: pgpimentel@hotmail.com

* Author for correspondence
} 
Os valores de $\mathrm{L}^{*}, \mathrm{a} * \mathrm{e} \mathrm{c}^{*}$ aumentam de forma linear com o tempo de maturação. Os valores $\mathrm{b} * \mathrm{e} \mathrm{h}$

* apresentaram uma regressão quadrática. A contagem de mesófilos e psicrotróficos apresentaram um aumento linear. $\mathrm{O}$ índice de fragmentação miofibrilar apresentou uma regressão quadrática, e a força de cisalhamento diminuiu linearmente. $\mathrm{Na}$ análise sensorial, uma diferença na intensidade de odor da carne foi observada. A contagem microbiológica indicou que a carne estava apta para consumo. A maturação promoveu melhorias na qualidade da carne de ovelhas.

Palavras-chave: Anaeróbia, croma, maciez, ovinos, sensorial

\section{Introduction}

One of the difficulties faced by sheep farmers is adding value to animal meat normally destined for disposal. The annual disposal percentage of a farm varies between 15 and 20\% (CAVALCANTE; LÔBO, 2005). The meat of these animals is not valued because of sensory characteristics such as accented aroma and flavor, a greater amount of carcass fat and reduced tenderness.

The meat of animals meant for disposal can be marketed as sausages, fermented or aged meat (PINHEIRO; SOBRINHO; BARBOSA, 2007). Knowledge of the physical characteristics of meat, such as $\mathrm{pH}$, color, water-holding capacity (WHC), and tenderness of the various age groups, is necessary in order to offer ovine meat in large quantities and high quality and improve its competitiveness against other sources of animal meat (BRESSAN et al., 2001).

The preferences of meat consumers have changed over time, particularly with regard to the search for better quality. Consumers believe tenderness to be most important organoleptic characteristic of meat (KOOHMARAIE, 1994). However, there is great variability in the tenderness of meat available to consumers; one method to reduce the variability and improve tenderness would be to promote meat aging.

Aging is the process of storing meat in natura for a period at refrigeration temperatures, causing an increase in tenderness and improvement in taste. The process consists of allowing the prolonged action of proteases naturally present in meat to perform proteolysis of some structural proteins of the sarcomere (KOOHMARAIE, 1989). This technique makes the meat more tender, as well as improving other sensory characteristics such as flavor and aroma, which result from the action of microbial enzymes to produce organic acids (VASCONCELOS et al., 2002).

Meat has high nutritional value and contains a high proportion of water, which makes it susceptible to microbial attack. The main objective of vacuum packaging is to protect fresh or processed meat from contact with oxygen, which induces the growth of aerobic microorganisms with a high potential to cause deterioration that can change the odor, color and appearance of meat products. Aerotolerant anaerobic lactic acid bacteria thrive in the absence of oxygen and at cooling temperatures, but produce only minor changes in the quality of the meat even at high counts (FORSYTHE, 2002).

The present work aimed to add value to ewe meat products through aging, improving meat tenderness and masking meat odor. The effects of aging on the sensory and microbiological quality of ewe meat were evaluated.

\section{Material and Methods}

The experiments were conducted in accordance with ethical standards and approved by the Ethics Committee on Animal Experimentation of the State University of Londrina (UEL) registered in the CEEA under number 58/09, Case number $13655 / 2009$. The study was conducted at the Farm School and the Laboratory of Analysis of Animal Products of the UEL.

Eighteen Santa Ines ewes of 6 years mean age were used. The animals were housed in a feedlot 
and fed twice a day ( 8 a.m. and 5 p.m.). The diet (Table 1) consisted of sorghum silage and ration concentrate (corn, soybean meal, soybean oil, sodium chloride and calcium carbonate) in a ratio of 60:40 (dry basis), with water ad libitum. The diet was formulated to meet the requirements established by the National Research Council - NRC (1985) for daily gains of $100 \mathrm{~g}$.

Table 1. Chemical composition of experimental feed and amount of magnesium.

\begin{tabular}{lc}
\hline \multicolumn{2}{c}{ Composition of the diet } \\
\hline Composition of concentrate & \\
\hline Dry matter (g/kg NM) & 856.5 \\
Crude protein (g/kg DM) & 113.9 \\
Ether extract (g/kg DM) & 40.7 \\
Crude fiber (g/kg DM) & 28.9 \\
Neutral Detergent Fiber (g/kg DM) & 164.9 \\
Acid Detergent Fiber $(\mathrm{g} / \mathrm{kg} \mathrm{DM})$ & 26.5 \\
ENERGIA (g/kg DM) & 802.2 \\
\hline Composition of sorghum silage & \\
\hline Dry matter (g/kg NM) & 240.5 \\
Crude protein (g/kg DM) & 75.4 \\
Ether extract (g/kg DM) & 26.6 \\
Neutral detergent fiber (g/kg DM) & 633.2 \\
Acid detergent fiber (g/kg DM) & 381.8 \\
ENERGIA (g/kg DM) & 598.3 \\
\hline Chemical composition of total mixed ration & \\
\hline Dry matter (g/kg NM) & 486.9 \\
Crude protein $(\mathrm{g} / \mathrm{kg} \mathrm{DM)}$ & 90.8 \\
Ether extract (g/kg DM) & 32.2 \\
Neutral Detergent Fiber (g/kg DM) & 445.9 \\
Acid Detergent Fiber $(\mathrm{g} / \mathrm{kg}$ DM) & 239.7 \\
ENERGIA (g/kg DM) & 679.9 \\
\hline
\end{tabular}

Source: Elaboration of the authors.

After slaughter, and 24 hours of cooling at $2^{\circ} \mathrm{C}$, both Longissimus dorsi muscles were collected. The muscle of the right half carcass was divided into 9 pieces ( $3 \mathrm{~cm}$ each): 3 for myofibrillar fragmentation indexing (MFI) and 6 for shear force (SF) and microbiological analysis. The muscle of the left half carcass was divided into 9 pieces: 3 (2 cm each) to perform color measurements and determine the $\mathrm{pH}$, water loss under pressure and 6 (2 $\mathrm{cm}$ each) for sensory evaluation. All samples were vacuum packed individually in an oxygen barrier film (16 $\mathrm{x}$ $22 \mathrm{~cm}-8 \mu \mathrm{m})$.

The samples were subjected to three stages of aging: T1 - zero days aging (control), T2 - four days aging at $5 \pm 2^{\circ} \mathrm{C}$ and $\mathrm{T} 3$ - eight days aging at $5 \pm 2^{\circ} \mathrm{C}$.

After the end of each aging period, a sample was taken, which was then measured for hydrogen potential $(\mathrm{pH})$ using a TESTO $^{\circledR} 205$ portable potentiometer with electrode insertion (Lenzkirch, DE). The water holding capacity was evaluated by pressure on filter paper (water loss under pressure) (BARBUT, 1996).

The color was analyzed using a portable MINOLTA $^{\circledR}$ CR-10 colorimeter with illuminant $\mathrm{C}$ and $8^{\circ}$ angle of inclination (Tokyo, JP) for the assessment of the components $\mathrm{L}^{*}$ (luminosity), 
$\mathrm{a}^{*}$ (red-green component) and $\mathrm{b}^{*}$ (yellow-blue component), which were expressed in the CIELAB color system with the model illuminant tilted by 8 degrees. With these values, the hue angle $\left(h^{*}\right)$ was calculated using equation $\mathrm{h}^{*}=\tan ^{-1}\left(\mathrm{~b}^{*} / \mathrm{a}^{*}\right)$ and the saturation index or chroma $\left(\mathrm{c}^{*}\right)$ using the equation $\mathrm{c}^{*}=(\mathrm{a} * 2+\mathrm{b} * 2) \quad 0.5$. The remaining samples were frozen at $-18^{\circ} \mathrm{C}$ for MFI, SF, microbiological and sensory analysis.

The myofibrillar fragmentation index was evaluated by the method proposed by Culler et. al. (1978). The shear force was objectively measured using a TA.XT-2 Texture Analyzer (Godalming, UK) with a 3-mm shear blade probe. To obtain the samples, it was used a cylindrical steel sampler. Two steaks per animal were used, which were roasted until they reached an internal temperature of $71^{\circ} \mathrm{C}$. Three sub-samples, approximately $1.25 \mathrm{~cm}$ in thickness and $2.5 \mathrm{~cm}$ high, were cut from each steak. Each sub-sample was sheared once, producing a total of six readings per animal (WHIPPLE et al., 1990).

Microbiological analysis was performed using the technique described by NBR 10203 (ABNT, 1988 ) involving surface smearing. A swab was used for each area of the loin, producing two swabs for each sample. These swabs were placed in a test tube containing $9 \mathrm{~mL}$ of buffered peptone water (BPW) diluent and were shaken in a vortex for two minutes.

From this first tube, which was diluted to $10^{-1}$ with BPW, further dilutions in BPW $10^{-2}, 10^{-3}, 10^{-4}$ and $10^{-5}$ were done. After dilution, the tube was agitated in a vortex for ten seconds before collection in the next tube and so on.

When all of the dilutions had been made, they were seeded by the pour plate technique on agar (Standard Methods Agar - PCA). One milliliter of each dilution was placed on a petri dish to search for mesophilic and psychrotrophic bacteria. Then, PCA agar heated to $45^{\circ} \mathrm{C}$ was poured over the dish and homogenized; after solidification of the agar, the samples were incubated at $35^{\circ} \mathrm{C}$ for 48 hours for mesophilic counting and $7^{\circ} \mathrm{C}$ for 72 hours for psychrotrophic counting.
After this period, it was performed counts of total $\mathrm{CFU} / \mathrm{cm}^{2}$ (colony forming units per square centimeter). Dish with 25 to $250 \mathrm{CFU}$ were selected for counting with a magnifying glass.

Tasters trained to assess odors, tenderness and juiciness in beef performed sensory analysis using a structured scale according to the methodology proposed by ABNT (1993). Eleven trained tasters were used to evaluate odor intensity ( 1 - extremely intense to 5 - no odor) and characterize the odor (fresh meat / chilled meat / fruity / aged / rancid and reheated), tenderness ( 1 - very hard to 7 - very tender), juiciness ( 1 - none to 5 - high) and overall acceptability ( 1 - extremely unacceptable to 9 extremely acceptable) of the samples.

Each professional taster received three samples (one control treatment with zero days of aging, another with four days aging and one with eight days aging), a glass of water, a saltine cracker and a container of coffee powder. Between each test, the mouth was cleaned and rinsed with water and crackers, and olfaction was cleared with coffee.

The data obtained were subjected to analysis of variance (ANOVA) with a polynomial derivation according to the aging time, and the data from the sensory analysis was subjected to ANOVA and Tukey's test at a significance level of 5\%. Pearson correlation coefficients were calculated using the statistical package SAS (2001).

\section{Results and Discussion}

It was observed that mesophilic microorganisms experienced increased growth with ewe meat aging in vacuum packaging (Table 2). The total count of aerobic mesophiles in plaques is the most widely used general indicator of bacterial populations in foods. However, this indicator does not differentiate between types of bacteria and is used for general information about the quality of raw products, manufacturing practices and product lifetime. 
Table 2. Microbiological parameters, $\mathrm{pH}$ and L* of the Longissimus dorsi muscle of culling ewes.

\begin{tabular}{|c|c|c|c|c|c|}
\hline \multirow{2}{*}{ Meat parameters } & \multicolumn{3}{|c|}{ Aging time } & \multirow[b]{2}{*}{$\mathrm{R}$} & \multirow[b]{2}{*}{$\mathrm{CV}(\%)$} \\
\hline & 0 days & 4 days & 8 days & & \\
\hline Mesophilic $\left(\log \mathrm{CFU} / \mathrm{cm}^{2}\right)$ & 2.01 & 2.42 & 3.01 & $\mathrm{~L}^{1}$ & 9.45 \\
\hline Psychrotrophic $\left(\log \mathrm{CFU} / \mathrm{cm}^{2}\right)$ & 1.99 & 2.55 & 2.96 & $\mathrm{~L}^{2}$ & 14.55 \\
\hline $\mathrm{pH}$ & 5.58 & 5.57 & 5.49 & $\mathrm{~L}^{3}$ & 1.46 \\
\hline
\end{tabular}

$\mathrm{CV}$ - coefficient of variation, $\mathrm{L}$ - linear, $\mathrm{Q}$ - quadratic, $\mathrm{R}$ - regression.

${ }^{1} \hat{y}=1.97+0.12 x\left(r^{2}=0.98\right) ;{ }^{2} \hat{y}=2.01+0.12 x\left(r^{2}=0.99\right) ;{ }^{3} \hat{y}=5.59-0.01 x\left(r^{2}=0.77\right)$.

Source: Elaboration of the authors.

The mesophilic count on non-aged meat was $2.2 \times 10^{4} \mathrm{CFU} / \mathrm{cm}^{2}$, where the low values indicate good hygienic handling of samples. According to Mano, Pereira e Fernando (2002), the useful lifetime of a product is the number of days required for the mesophilic count to reach a value of $10^{7}$ $\mathrm{CFU} / \mathrm{cm}^{2}$. In this work, meat aged for 8 days at 5 $\pm 2^{\circ} \mathrm{C}$ showed values of $1.5 \times 10^{6} \mathrm{CFU} / \mathrm{cm}^{2}$, which indicates that the meat was fit for consumption and could be stored for a few more days before reaching the end of its useful life.

The psychrotrophic plate count also showed a linear increase with aging (Table 2). Psychrotrophs are microorganisms that grow in food under refrigeration $\left(0-15^{\circ} \mathrm{C}\right)$; some possess a high potential to contaminate and spoil refrigerated products, as is the case with clostridium $\mathrm{sp}$, enterobacter $\mathrm{sp}$, escherichia $\mathrm{sp}$, listeria $\mathrm{sp}$ and pseudomonas sp. Others, such as bacillus sp and lactobacillus sp, cause only minor changes in meat products even at high counts.

The $\mathrm{pH}$ value (Table 2) decreased linearly with increasing aging time $(\mathrm{P}=0.0031)$. Gonçalves et al. (2004) and Maggioni (2009) also observed a reduction in the $\mathrm{pH}$ lamb meat with increasing aging time.

The growth of psychrotrophic bacteria is intimately linked to the $\mathrm{pH}$ of the meat. The initial $\mathrm{pH}$ of meat facilitates the growth of microorganisms; a low $\mathrm{pH}$ of 5.4 to 5.6 facilitates the growth of lactic acid bacteria, whereas a $\mathrm{pH}$ of 5.8 to 6.0 facilitates the growth of pseudomonas sp because the lactic acid bacteria will have too many competitors to prevail (MANO; PEREIRA; FERNANDO, 2002).
The lactobacillus spp are Gram positive and oxygen-tolerant. They produce lactic acid and promote a decrease in the $\mathrm{pH}$ of meat, thus reducing the growth of pseudomonas sp. The production of ammonia and amines from amino acids and urea is an important indicator of the deterioration process and results in increased $\mathrm{pH}$ values (ERCOLINI et al., 2006).

In this study, we observed that the psychrotrophic count increased from $2.1 \times 10^{4}$ in non-aged meat to $1.3 \times 10^{6} \mathrm{CFU} / \mathrm{cm}^{2}$ in meat aged for eight days. In conjunction with this growth, there was a reduction in the $\mathrm{pH}$ of the meat, possibly indicating the growth of lactic acid bacteria to the detriment of pseudomonas sp. Puga, Contreras e Turnbull (1999) also observed an increase in the number of lactic acid bacteria during maturation. This is because the initial $\mathrm{pH}$ of the meat and vacuum packaging induce the growth of lactic acid bacteria.

With respect to the color components (Table 2), the $\mathrm{L}^{*}$ value increased $(\mathrm{P}=0.0002)$ with aging, i.e., the meat became lighter. Gonçalves et al. (2004) and Zeola et al. (2007a) found no difference in the $L^{*}$ value, whereas Apple et al. (2001) and Maggioni (2009) found an increase in the $L^{*}$ value. This result can be explained by the negative correlation between $\mathrm{L}^{*}$ and $\mathrm{pH}$. When the $\mathrm{pH}$ of the meat is low (5.6), the myofibrillar proteins are at their isoelectric point, i.e., they have the same amount of positive and negative charges, and fail to bind to water, which goes to the surface and reflects light, resulting in a higher $\mathrm{L}^{*}$ value. 
According to Pinheiro et al. (2009) ovine meat color becomes darker with increasing age and weight at slaughter due to the increase in myoglobin pigment. As observed, the aging of the meat can act to lighten the color, which may increase the acceptability of meat from animals meant for disposal.

The aging of meat increased the $\mathrm{a}^{*}$ component $(\mathrm{P}=0.0033)$ and the $\mathrm{b}^{*}$ component $(\mathrm{P}=0.0001)$, i.e., the aged meat had the highest intensity of red and yellow pigment. The same was observed by Apple et al. (2001), Zeola et al. (2007a) observed an increase in the $a^{*}$ value, although the $b^{*}$ value was not affected by aging.

According to Gill e Holley (2005) when fresh meat is vacuum packed, the metamyoglobin formed in muscle tissue due to the absorption of residual oxygen is converted to deoxymyoglobin for the reductase activity $\left(\mathrm{NAD}^{+}\right)$of the muscle; when the meat is exposed to air, this will result in an initial bright red bloom. According to Zeola et al. (2007a), aged meat, even after the equalization of color, still shows a gradient differential when compared to non-aged meat.

The calculations made from the color components yielded chroma values, which indicate the color saturation (the difference between pastel or bright), and tone values, which characterize the amount of color, where these values allow different samples to be differentiated. The chroma value increased linearly ( $\mathrm{P}=0.0013)$ with increasing aging time, i.e., the aged meat had a more vivid color, related to the increase in the components $a^{*}$ and $b^{*}$. The tone showed a quadratic regression $(\mathrm{P}=0.0001)$ influenced by the value of $b^{*}$.

Only the water loss during thawing (Table 3) was influenced by the aging time $(\mathrm{P}=0.0817)$, where this decreased as the maturation time increased. The same was observed by Apple et al. (2001). However, Maggioni (2009) observed an increase in water loss during thawing with aging; according to the author, the proteolysis that occurs during aging may have triggered the disruption of cell membranes, resulting in higher water losses.

Table 3. Mean values of the characteristics of ovine Longissimus dorsi muscle with different aging times.

\begin{tabular}{lccccc}
\hline \multirow{2}{*}{ Meat quality parameters } & \multicolumn{3}{c}{ Aging time } & \multicolumn{2}{c}{ CV\% } \\
\cline { 2 - 4 } & 0 days & 4 days & 8 days & R & CV \\
\hline $\mathrm{L}^{*}$ (lightness) & 33.35 & 35.05 & 35.63 & $\mathrm{~L}^{1}$ & 4.22 \\
$\mathrm{a}^{*}$ (red-green component) & 19.40 & 19.48 & 20.91 & $\mathrm{~L}^{2}$ & 6.86 \\
$\mathrm{~b}^{*}$ (yellow-blue component) & 7.18 & 8.39 & 8.54 & $\mathrm{Q}^{3}$ & 9.57 \\
$\mathrm{c}^{*}$ (chroma) & 20.70 & 21.22 & 22.59 & $\mathrm{~L}^{4}$ & 6.66 \\
$\mathrm{~h}^{*}\left({ }^{\circ}\right.$ (tone) & 20.35 & 23.32 & 22.23 & $\mathrm{Q}^{5}$ & 8.03 \\
Water loss under pressure (\%) & 28.47 & 28.59 & 29.90 & $\mathrm{n} . \mathrm{s}$ & 23.95 \\
Water loss during thawing (\%) & 6.60 & 4.89 & 5.19 & $\mathrm{~L}^{6}$ & 42.22 \\
Water loss during cooking (\%) & 25.71 & 25.03 & 24.72 & $\mathrm{n} . \mathrm{s}$ & 5.44 \\
Shear force (kgF) & 3.48 & 3.15 & 3.04 & $\mathrm{~L}^{7}$ & 12.02 \\
Myofibrillar fragmentation index (\%) & 94.86 & 94.17 & 96.96 & $\mathrm{Q}^{8}$ & 2.99 \\
\hline
\end{tabular}

$\mathrm{ns}$ - not significant $(\mathrm{P}>0.10), \mathrm{CV}$ - coefficient of variation, $\mathrm{L}$ - linear, $\mathrm{Q}$ - quadratic, $\mathrm{R}$ - regression.

${ }^{1} \hat{y}=33.54+0.28 x\left(r^{2}=0.92\right) ;{ }^{2} \hat{y}=19.17+0.18 x\left(r^{2}=0.73\right) ;$

${ }^{3} \hat{y}=7.17+0.43 x-0.03 x^{2}\left(r^{2}=0.35\right) ; \hat{y}=20.55+0.23 x\left(r^{2}=0.93\right)$;

${ }^{5} \hat{y}=20.34+1.22 \mathrm{x}-0.12 \mathrm{x}^{2}\left(\mathrm{r}^{2}=0.31\right) ;{ }^{6} \hat{\mathrm{y}}=6.25-0.17 \mathrm{x}\left(\mathrm{r}^{2}=0.60\right)$;

${ }^{7} \hat{y}=3.44-0.05 x\left(r^{2}=0.92\right) ;{ }^{8} \hat{y}=94.85-0.6 x+0.1 x^{2}\left(r^{2}=0.03\right)$.

Source: Elaboration of the authors. 
According to Miller et al. (1996) the exudate present in the packing increases with aging. The same was observed in this experiment, where the aged meats had already lost much of the water during the aging process, thus containing less water to lose in thawing compared to the non-aged meat.

The myofibrillar fragmentation index (Table 3 ), which is an indicator of the fragmentation of sarcomeres in myofibrils, showed quadratic behavior $(\mathrm{P}=0.0176)$, and the highest value was observed after 8 days of aging. Values near 30 indicate stiff muscles, values close to 60 soft muscles and values close to 100 very soft muscles. Because the values ranged from 94 to 96 , we observed that this muscle was already very soft before aging, with slight increases in tenderness (3.4 to $3 \mathrm{kgf}$ ) with aging.
High values were expected for the shear force because the animals were 6 years old and destined for disposal. However, Pinheiro et al. (2009) observed shear force values in ewes similar to those of adult wethers and lambs: 1.52, 1.64 and 1.79, respectively, for the loin.

Despite the small decrease in the shear force with increasing aging, this difference was significant $(\mathrm{P}$ $=0.0047)$. According to Taylor et al. (1995), it has long been known that meat tenderness increases when it is stored at cool temperatures. Apple et al. (2001), Zeola et al. (2007b) and Maggioni (2009) have observed a reduction in shear force with aging.

In the sensory evaluation performed by trained tasters (Table 4), it was observed that the meats differed only in odor intensity. The non-aged meat presented an intense odor, whereas the meat aged for eight days presented moderate odor.

Table 4. Characterization of the Longissimus dorsi odor of culling ewes.

\begin{tabular}{llll}
\hline Sensory evaluation parameters & \multicolumn{3}{c}{ Aging time } \\
\cline { 2 - 4 } & 0 days & 4 days & 8 days \\
\hline Odor intensity & $2.64 \mathrm{a}$ & $3.36 \mathrm{ab}$ & $3.73 \mathrm{~b}$ \\
Softness & 6.27 & 6.09 & 6.45 \\
Succulence & 4.27 & 4.18 & 4.18 \\
Overall acceptability & 7.18 & 7.45 & 7.36 \\
\hline
\end{tabular}

Means followed by different letters are significantly different $(\mathrm{P}<0.10)$.

Source: Elaboration of the authors.

Some tasters sensed a more intense animal odor in meat that was not aged compared to meat that was aged for 4 and 8 days, i.e., the organic acids produced by bacteria during ripening served to mask the odor. Regarding the other parameters, the meat was considered tender, with moderate and moderately acceptable juiciness.

Another evaluation was performed to characterize the odor, where $45 \%, 82 \%$ and $73 \%$ of the panelists reported the odor of fresh meat in non-aged meat and meat aged for four and eight days, respectively. In addition, $18 \%$ of the panelists reported the odor of aged meat during four and eight days at $5 \pm 2{ }^{\circ} \mathrm{C}$, although this did not negatively affect the overall acceptability of the sample. It is interesting to note that the non-aged meat was also reported to smell of stale, reheated meat, even fruity and refrigerated meat, but that this was not detected in the aged meat.

The marbling (Table 5) was correlated (0.456) with the myofibrillar fragmentation index, the greater the amount of fat marbling in the muscle, the greater its softness. The water loss during the cooking of the meat was positively correlated with shear force and negatively correlated with myofibrillar fragmentation. Thus, the higher the observed water loss, the greater the force required 
to cut that meat and the lower the fragmentation index, indicating a reduction in meat tenderness.

There was a negative correlation between meat $\mathrm{pH}$ and water loss during cooking (-0.303), i.e., the higher the $\mathrm{pH}$ of the meat, the lower the water loss during cooking due to a higher water-retention capacity (WRC).

François (2009) observed that darker meat has a coarser texture, although this result was not observed in this work. No color component was correlated with characteristics associated with meat texture.

The aging of ewe meat lowers the $\mathrm{pH}$, improves the color of the meat by making it lighter and improves meat tenderness. All of these changes can improve the acceptability of the meat by consumers. The aging process of ewe meat in vacuum packaging for up to eight days increases the mesophilic and psychrotrophic microbial flora count, although the meat maintains acceptable values, making it adequate for consumption. The aging process masks the animal odor of the meat, which may improve the acceptance of the product by consumers.

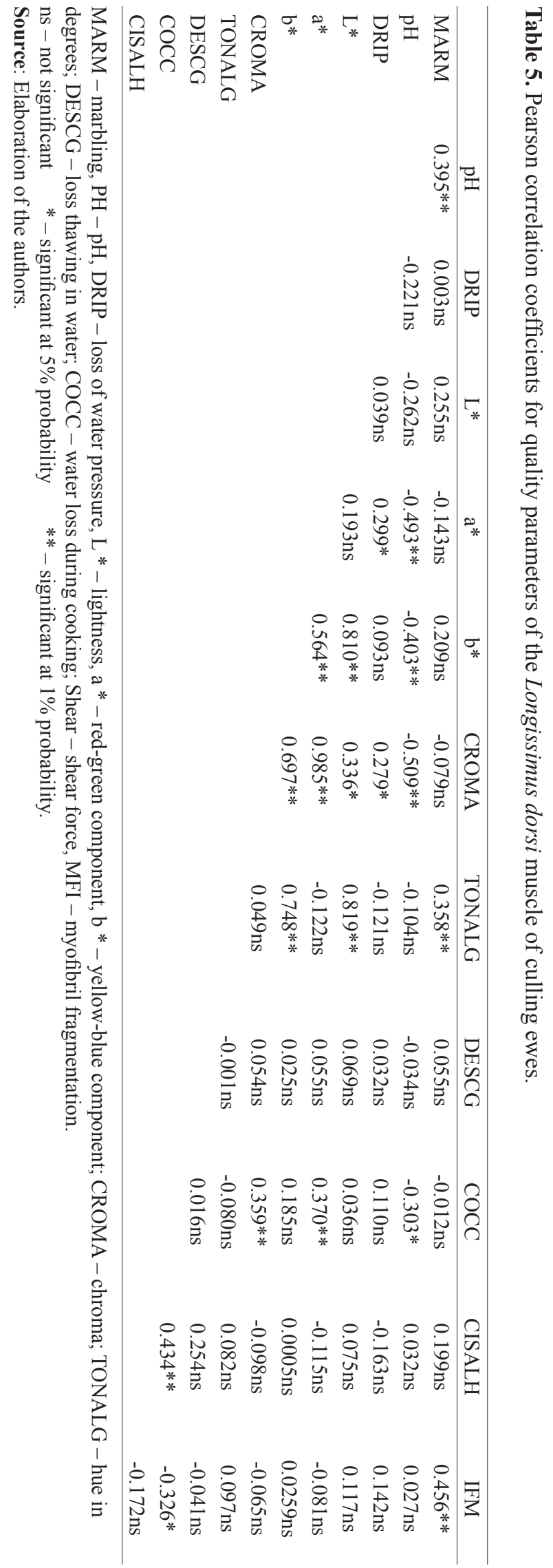




\section{Acknowledgments}

The authors are thank full to $\mathrm{CNPq}$ and Foundation Araucária for the financial support.

\section{References}

APPLE, J. K.; DAVIS, J. R.; RAKES, L. K.; MAXWELL, C. V.; STIVARIUS, M. R.; POHLMAN, F. W. Effects of dietary magnesium and duration of refrigerated storage on the quality of vacuum-packaged, boneless pork loins. Meat Science, Missouri, v. 57, n. 1, p. 43-53, 2001.

ASSOCIAÇÃO BRASILEIRA DE NORMAS TÉCNICAS - ABNT. NBR 10203. Preparo da amostra para exame microbiológico. Rio de Janeiro: ABNT. mar. 1988.

NBR 12994. Métodos de Análise sensorial dos alimentos - classificação. Rio de Janeiro: ABNT. jul. 1993.

BARBUT, S. Estimates and detection of the PSE problem in young turkey breast meat. Canadian Journal of Animal Science, Ottawa, v. 76, n. 2, p. 455-457, 1996.

BRESSAN, M. C.; PRADO, O. V.; PÉREZ, J. R. O.; LEMOS, A. L. S. C.; BONAGURIO, S. Efeito do peso ao abate de cordeiros Santa Inês e Bergamácia sobre as características físico-químicas da carne. Ciência e Tecnologia de Alimentos, Campinas, v. 21, n. 3, p. 293303, 2001.

CAVAlCANTE, A. C. R.; LÔBO, R. N. B. Sistema de produção de caprinos e ovinos de corte para o nordeste brasileiro. Embrapa, 2005.

CULLER, R. D.; PARRISH, F. C.; SMITH, G. C.; CROSS, H. R. Relationship of myofibril fragmentation index to certain chemical, physical and sensory characteristics of bovine Longissimus muscle. Journal of Food Science, Chicago, v. 43, n. 4, p. 1177-1180, 1978.

ERCOLINI, D.; RUSSO, F.; TORRIERI, D.; MAIS, P.; VILLANI, F. Changes in the spoilage-related microbiota of beef during refrigerated storage under different packaging conditions. Applied and Environmental Microbiolog, Washington, v. 72, n. 7, p. 4663-4671, 2006.

FORSYTHE, S. J. Microbiologia da segurança alimentar. Porto Alegre: Editora, 2002. 424 p.

FRANÇOIS, P. Desempenho, características de carcaça e a utilização da carne de ovelhas de descarte terminadas em pastagem cultivada na elaboração de embutido fermentado. 2009. Dissertação (Mestrado em Zootecnia) - Universidade Federal de Santa Maria, Santa Maria.
GILL, C. O.; HOLLEY, R. A. Mechanisms of colour changes in fresh and processed meat. In: CONGRESSO BRASILEIRO DE CIÊNCIA DE TECNOLOGIA DE CARNEs, 3., 2005, Campinas. Anais... São Paulo: Instituto de Tecnologia de Alimentos, 2005. CD-ROM.

GONÇALVES, L.A. G.; ZAPATA, J. F. F.; RODRIGUES, M. C. P.; BORGES, A. S. Efeitos do sexo e do tempo de maturação sobre a qualidade da carne ovina. Ciência e Tecnologia de Alimentos, Campinas, v. 24, n. 3, p. 459467, 2004.

KOOHMARAIE, M. Muscle proteinases and meat ageing. Meat Science, Missouri, v. 36, n. 2, p. 93-104, 1994.

The role of endogenous proteases in meat tenderness. In: PROCEEDINGS OF ANNUAL RECIPROCAL MEAT CONFERENCE, 41., 1988, Wyoming. Anais... USA: [s.n], 1989. p. 89-100.

MAGGIONI, D. Produção e qualidade da carne de bovinos cruzados (Bos taurus taurus vs. Bos taurus indicus) submetidos a duas dietas e abatidos com dois graus de acabamento. 2009. Tese (Doutorado em Zootecnia) - Universidade Estadual de Maringá, Maringá.

MANO, S. B.; PEREIRA, J. A. O.; FERNANDO, G. D. G. Aumento da vida útil e microbiologia da carne suína embalada em atmosfera modificada. Ciência e Tecnologia de Alimentos, Campinas, v. 22, n. 1, p. 1-10, 2002.

MILlER, M. F.; CARR, M. A.; SCHLUTTER, A. R.; JONES, D. K.; MEADE, M. K.; RAMSEY, C. B. Distribution packaging method and storage time on microbiological characteristics and incidence of the pathogens Listeria monocygenes and Salmonella in pork. Journal of Food Quality, n. 19, p. 413-422, 1996.

NATIONAL RESEARCH COUNCIL - NRC. Nutrient requirements of domestic animals: nutrient requirements of sheep. Washington: D.C.: National Academy Press, 1985.

PINHEIRO, R. S. B.; SOBRINHO, A. G. S.; ALVES, H. B.; YAMAMOTO, S. M. Qualidade de carnes provenientes de cortes da carcaça de cordeiros e de ovinos adultos. Revista Brasileira de Zootecnia, Brasília, v. 38, n. 9, p. 1790-1796, 2009.

PINHEIRO, R. S. B.; SOBRINHO, S. M.; BARBOSA, J. C. Composição tecidual dos cortes da carcaça de ovinos jovens e adultos. Pesquisa Agropecuária Brasileira, Brasília, v. 42, n. 4, p. 565-571, 2007.

PUGA, D. M. U.; CONTRETAS, C. J. C.; TURNBULL, M. R. Avaliação do amaciamento de carne bovina de dianteiro (Tríceps brachii) pelo métodos de maturação, 
estimulação elétrica, injeção de ácidos e tenderização mecânica. Ciência e Tecnologia de Alimentos, Campinas, v. 19, n. 1, p. 88-96, 1999.

STATISTICAL ANALYSIS SYSTEM - SAS. System for microsoft windows: release 8.2. Cary: 2001. CD-ROM.

TAYLOR, R. G.; GEESINK, G. H.; THOMPSON, V. F.; KOOHMARAIE, M.; GOLL, D. E. Is Z-disk degradation responsible for postmortem tenderization. Journal of Animal Science, Illinois, v. 73, n. 5, p. 1352-1367, 1995.

VASCONCELOS,E.C.;ZAPATA, J.F.F.;FIGUEIREDO, E. A.; CASTELO BRANCO, M. A. A.; BORGES, A. S. A microbiota da carcaça e da carne ovina tratada com ácido acético, embalada a vácuo e maturada por 48 dias. Ciência e Tecnologia de Alimentos, Campinas, v. 22, n. 3, p. 272-277, 2002.
WHIPPLE, G.; KOOHMARAIE, M.; DIKEMAN, M. E.; CROUSE, J. D. Predicting beef-Longissimus tenderness from various biochemical and histological muscle traits. Journal of Animal Science, Illinois, v. 68, n. 12, p. 41934199, 1990.

ZEOLA, N. M. B. L.; SOUZA, P. A.; SOUZA, H. B. A.; SOBRINHO, A. G. A. Parâmetros qualitativos da carne ovina: um enfoque à maturação e marinação. Revista Portuguesa de Ciências Veterinárias, Lisboa, v. 102, n. 563-564, p. 215-224, $2007 \mathrm{~b}$.

ZEOLA, N. M. B. L.; SOUZA, P. A.; SOUZA, H. B. A.; SOBRINHO, A. G. S.; BARBOSA, J. C. Cor, capacidade de retenção de água da carne de cordeiros maturada e injetada com cloreto de cálcio. Arquivo Brasileiro de Medicina Veterinária e Zootecnia, Minas Gerais, v. 59, n. 4, p. 1058-1066, 2007a. 